\title{
Modeling IPO In Dubai Stock Market: Booming Or Tumbling Return?
}

Viviane Y. Naïmy, (E-mail: nvnaimy@cyberia.net.lb), Notre Dame University, Lebanon

\begin{abstract}
This paper examines the impact of IPO on Dubai Stock Market. We measured through detailed distribution analysis and hypothesis testing the Dubai market's reaction to IPO. We demonstrated that IPO had downbeat impact on Dubai market performance in terms of return as revealed by the rejection of the alternative hypothesis. The independency between market return and IPO was partially attributed to irrational valuations at the time of IPO.
\end{abstract}

\section{INTRODUCTION}

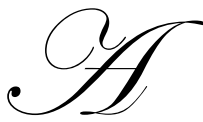

s a privately held firm expands, it may need more funds than it can obtain through borrowing and therefore will consider an initial public offering (IPO). A common first step for a growing firm is to obtain private equity funding from venture capitalist (VC) firms, which seek to invest in firms that offer high potential for growth over time. Therefore, an IPO is commonly used not only to obtain new funding but also to offer VC firms a way to cash in their investment ${ }^{1}$.

IPO issued in the Middle East has been booming since 2000. In 2005, the IPO market in Dubai touched Dh 40 billion. There have been complaints about how these IPO are taking out liquidity from the stock market causing the markets to crash. On April 12, the Saudi stock market tumbled by $14.2 \%$. It was no coincidence that in the same week the initial public offering of the Saudi Research \& Marketing Group received \$388 million in 582,000 subscription applications, leaving the IPO $132 \%$ oversubscribed. Neither it is by chance that the market fell at the same time when IPO were issued.

Dubai is experiencing unprecedented growth in its economy and particularly in its stock market ${ }^{2}$. The number of companies listed and traded has witnessed ${ }^{3}$ serious increase since 2001. However, IPO's issuance affected the performance of this market. Consequently, we decided to measure and analyze the impact of IPO on Dubai Financial Market's performance.

Section one describes data collection and lays out the variables distribution analysis with application of empirical rules on Dubai stock market. Section two is devoted to hypothesis testing and market's reaction modeling.

\footnotetext{
${ }^{1}$ Many VC firms sell their shares in the secondary market between 6 and 24 months after the IPO.

${ }^{2}$ The Dubai Financial Market (DFM) was officially founded in March 2000 as the first organized stock market in Dubai. DFM includes about thirty five listed stocks, out of which only twenty can be considered as being actively traded. The breadth and depth of industries is also limited - most of the listed stocks are in the banking and insurance sectors, with the remaining stocks being in a wide range of real estate and other services related sectors.

${ }^{3}$ For more details about this market see:

Naimy V., " Independency or Correlation? The GCC Stock Markets, Interest Rates, and Oil Prices: Against All Financial Rules", International Business \& Economics Research Journal, to appear in February 2007,

Naimy V., "Financial Ratios and Stock Prices: Consistency or Discrepancy? Longitudinal Comparison between UAE and USA", Working paper to be submitted to the 2006 International Business and Economics Research Conference, Nevada - USA.
} 


\section{DATA COLLECTION, VARIABLES DISTRIBUTION FUNCTIONS ANALYSIS, AND EMPIRICAL RULES}

\section{Data Collection}

We have used the weekly closing values for Dubai Market index for the period 2004-2006 according to the following monthly distribution ${ }^{4}: 2004$ (Apr - Dec), 2005 (Jan - Dec), and 2006 (Jan - Apr).Then, weekly market returns have been calculated. We also listed the IPO's issued in UAE according to their size, date, and volume ${ }^{5}$. Table 1 shows the description of each IPO's issuance.

Table 1: List Of IPO's Issuers Per Year, Per Size, And Per Volume

\begin{tabular}{|c|c|c|c|c|c|c|}
\hline Issuer & Year & $\begin{array}{c}\text { Issuance } \\
\text { Type }\end{array}$ & Sector & Size & Equity & $\begin{array}{c}\text { Over } \\
\text { subscription }\end{array}$ \\
\hline $\begin{array}{l}\text { Emirates Integrated } \\
\text { Telecommunications } \\
\text { Company }\end{array}$ & 2006 & IPO & $\begin{array}{l}\text { Telecoms and } \\
\text { IT }\end{array}$ & $\$ 659.92 \mathrm{M}$ & $20 \%$ & x 167.00 \\
\hline Tamweel & 2006 & IPO & $\begin{array}{l}\text { Financial } \\
\text { Services }\end{array}$ & $\$ 149.75 \mathrm{M}$ & $55 \%$ & x 484.00 \\
\hline Dana Gas & 2005 & IPO & Oil and Gas & $\$ 560.8 \mathrm{M}$ & $34.33 \%$ & x 140.00 \\
\hline $\begin{array}{l}\text { Abu Dhabi National } \\
\text { Energy Company } \\
\text { (Taqa) }\end{array}$ & 2005 & Privatization & $\begin{array}{l}\text { Power and } \\
\text { Utilities }\end{array}$ & $\$ 163.50 \mathrm{M}$ & $14.45 \%$ & x 350.00 \\
\hline $\begin{array}{l}\text { Sorouh Real Estate } \\
\text { Company }\end{array}$ & 2005 & IPO & Real Estate & $\$ 374 \mathrm{M}$ & $55 \%$ & x 176.00 \\
\hline $\begin{array}{l}\text { Aabar Petroleum } \\
\text { Investments }\end{array}$ & 2005 & IPO & Oil and Gas & $\$ 134.77 \mathrm{M}$ & $55 \%$ & x 800.00 \\
\hline RAK Properties & 2005 & IPO & Real Estate & $\$ 299.48 \mathrm{M}$ & $55 \%$ & x 57.00 \\
\hline $\begin{array}{l}\text { Arab International } \\
\text { Logistics Company }\end{array}$ & 2005 & IPO & Transport & \$149.74M & $55 \%$ & x 80.00 \\
\hline $\begin{array}{l}\text { Emirates Foodstuff } \\
\text { and Mineral Water } \\
\text { Company }\end{array}$ & 2004 & Privatization & $\begin{array}{l}\text { Agriculture } \\
\text { and Food }\end{array}$ & $\$ 80 \mathrm{M}$ & $49 \%$ & x 8.00 \\
\hline ALDAR Properties & 2004 & IPO & Real Estate & $\$ 224 \mathrm{M}$ & $55 \%$ & $\mathrm{x} 448.00$ \\
\hline $\begin{array}{l}\text { Arab Technical } \\
\text { Construction } \\
\text { Company }\end{array}$ & 2004 & IPO & Construction & $\$ 60 \mathrm{M}$ & $55 \%$ & x 65.00 \\
\hline Finance House $(\mathrm{FH})$ & 2004 & IPO & $\begin{array}{l}\text { Financial } \\
\text { Services }\end{array}$ & $\$ 30 \mathrm{M}$ & $55 \%$ & x 75.00 \\
\hline Amlak Finance & 2004 & IPO & $\begin{array}{l}\text { Financial } \\
\text { Services }\end{array}$ & $\$ 112 \mathrm{M}$ & $55 \%$ & x 34.00 \\
\hline $\begin{array}{l}\text { Emirates Integrated } \\
\text { Telecommunications } \\
\text { Company }\end{array}$ & 2006 & IPO & $\begin{array}{l}\text { Telecoms and } \\
\text { IT }\end{array}$ & $\$ 659.92 \mathrm{M}$ & $20 \%$ & x 167.00 \\
\hline
\end{tabular}

${ }^{4}$ www.zawya.com

${ }^{5}$ In other word, over subscriptions have been counted. 


\section{Time Series Analysis}

Figure 1: Time Series Illustrating The Market Index Trend With Comparison

To The Issued IPO For The Period 2004-2006

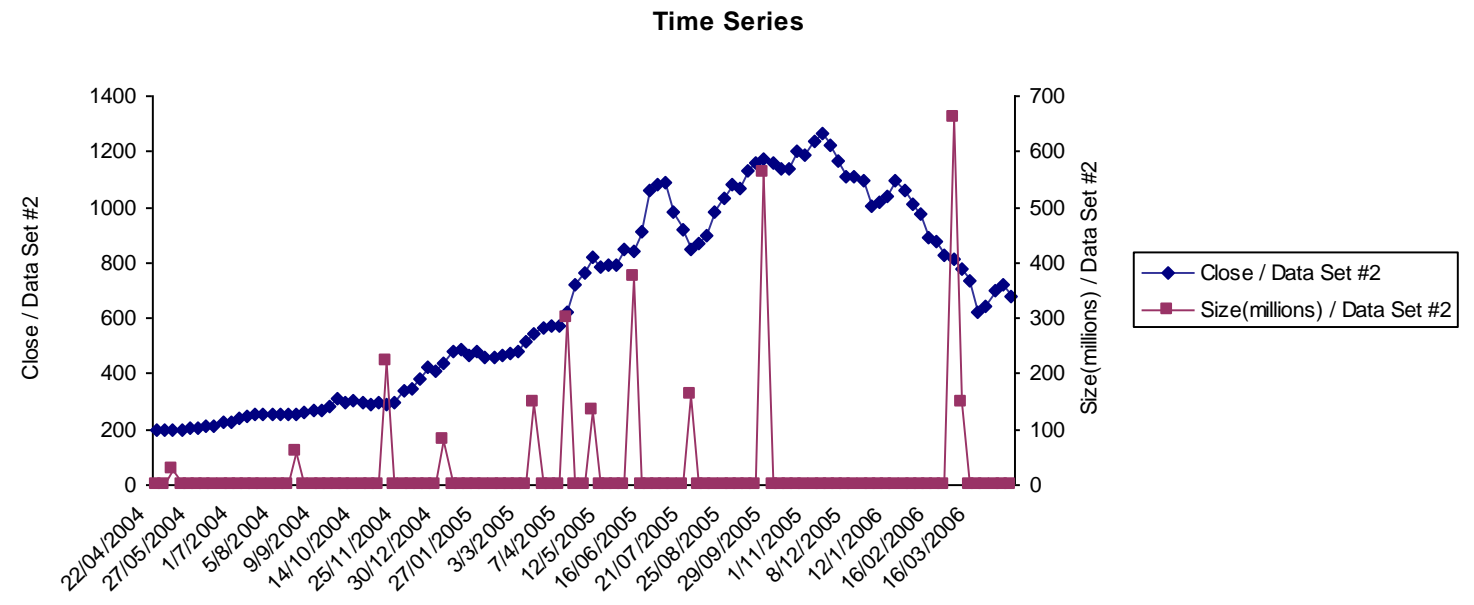

The time series shows that the market index has been rising over time. However, in 2006, the index fell to 678.14 by the end of the $2^{\text {nd }}$ week of April, a drop of $33.2 \%$, as compared to 1015.04 at the end of 2005. Comparing the market performance together with the IPO's issuance, we can easily notice that with each issuance exceeding the \$ 500 million, there has been a slight drop in the market index ${ }^{6}$. Nonetheless, and unlike investors' expectations, it was obvious that most of the time a risen market trend was registered with IPO's issuance.

Table 2 depicts the skewness and few measures of the central location of the index values and returns respectively.

Table 2: Descriptive Statistics - One Variable Summary

For The Market Closing Index And The Market Returns

\begin{tabular}{|c|c|c|}
\hline & Closing Values & Returns \\
\hline Mean & 664.13 & $1.27 \%$ \\
\hline Variance & 120429.20 & $5.28 \%$ \\
\hline Std. Dev. & 347.03 & $5.29 \%$ \\
\hline Skewness & 0.1266 & $391.12 \%$ \\
\hline Kurtosis & 1.5327 & $1.07 \%$ \\
\hline Median & 635.52 & $3.93 \%$ \\
\hline Mean Abs. Dev. & 312.04 & $-15.32 \%$ \\
\hline Minimum & 196.58 & $16.67 \%$ \\
\hline Maximum & 1266.38 & $31.99 \%$ \\
\hline Range & 1069.80 & $-1.75 \%$ \\
\hline 1st Quartile & 295.25 & $3.83 \%$ \\
\hline 3rd Quartile & 998.87 & $5.58 \%$ \\
\hline Interquartile Range & 703.62 & \\
\hline
\end{tabular}

${ }^{6}$ In 2006 the market index fell by $46 \%$ off its all time high (1266.38, Table 2). 
Given the skewness of both variables, the average ${ }^{7}$ return of the market was $1.07 \%$ for the period 2004-2006. $25 \%$ of the measured index' values were below 295.25 and witnessed a negative return averaging, $-1.75 \%$, whereas, $75 \%$ of these values were below 998.87 with a positive return close to $4 \%$. This shows that the market has been positively and fairly performing over this period.

Figure 2 compares the market return performance with the IPO's issuance.

Figure 2: Market Returns Versus IPO's

Time Series

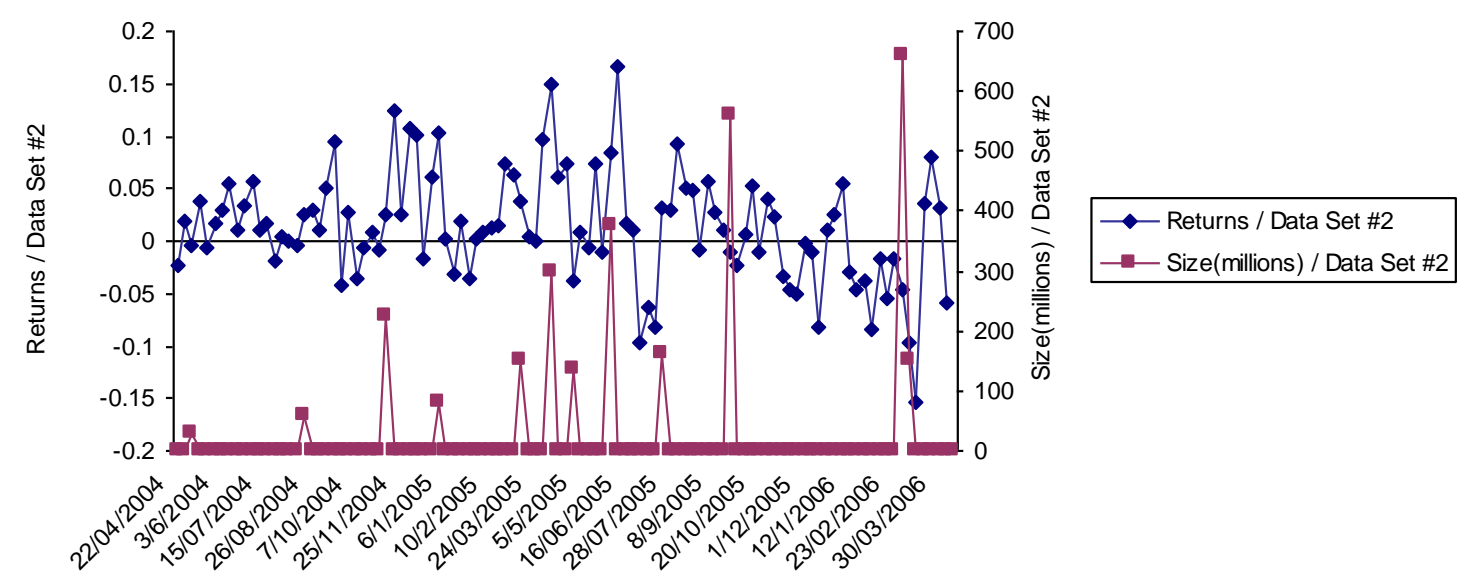

Although the Market Index clearly showed a fairly steady rise over the period, the returns did not exhibit any obvious trend. This is corroborated in table 2 that indicates an average return of $1.07 \%$ with a standard deviation of $5.29 \%$. In order to check the possibility of using the empirical rules to better interpret the market performance, a "fit" test is done for the market returns' distribution.

The first best fit distribution is the logistic with a chi square of 6.53 , followed by the normal distribution ${ }^{8}$. Therefore, results in Table 1 can be interpreted using the empirical rules for the market return variable.

\section{Applying Empirical Rules On Dubai Market Returns}

Using the mean of $1.27 \%$ (instead of the median) and a standard deviation of $5.29 \%$, we can deduce that during the three-year period, $68 \%$ of the time, the Dubai market had a return ranging between $-4.02 \%$ and $6.56 \%$, 95\% of the time, the Dubai market had a return ranging between $-9.31 \%$ and $11.85 \%$, and $99 \%$ of the time, this market had a return ranging between $-14.6 \%$ and $17.14 \%$. These results are not completely accurate due to the slight skewness of returns and to the approximate normal distribution that we have obtained in the second place.

\footnotetext{
${ }^{7}$ It is more significant to consider the median instead of the mean.

${ }^{8}$ Chi- sq $=13.69$
} 
Figure 3: Best-Fit Test For The Market Returns

Logistic(0.012079, 0.028830)

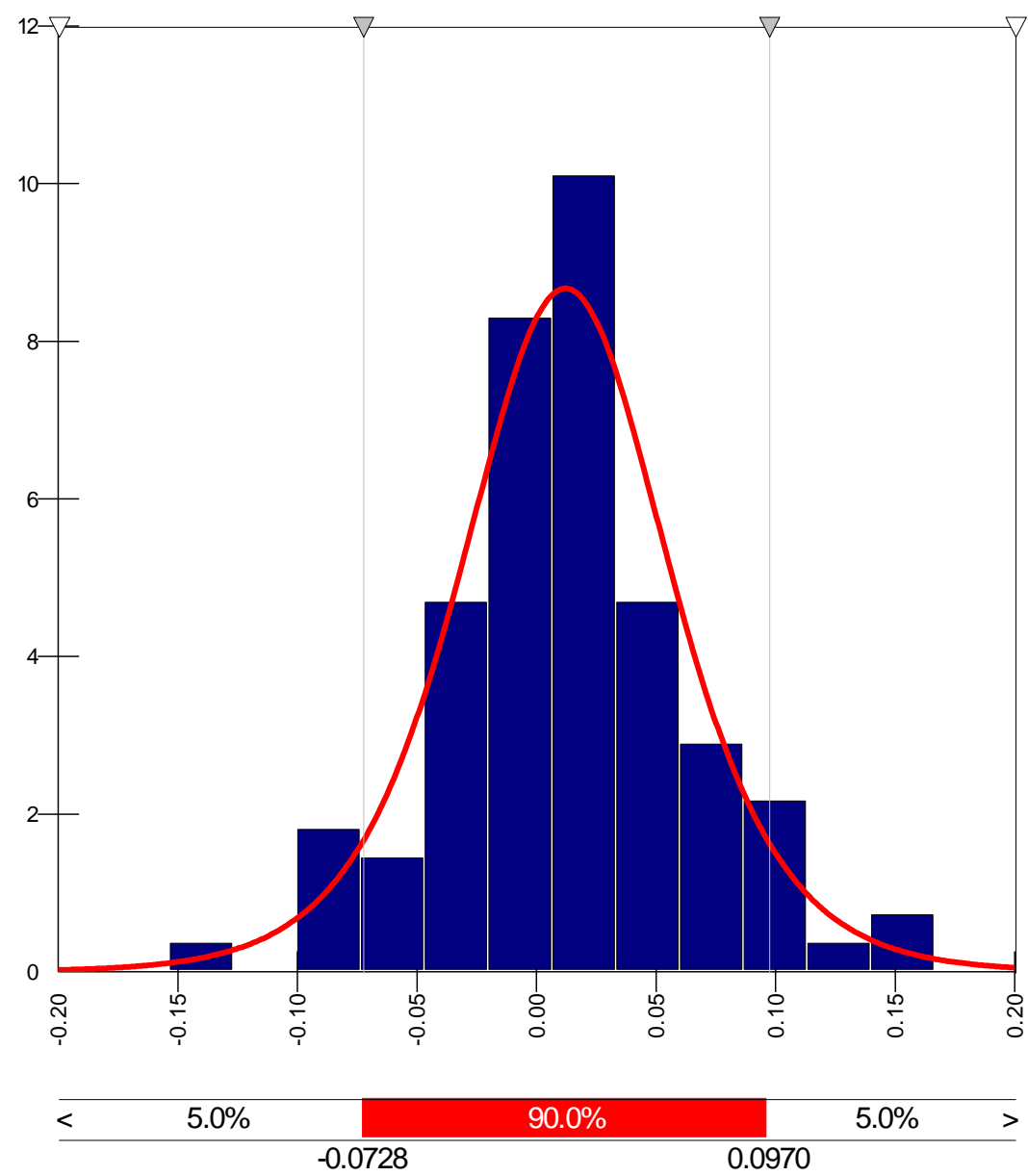

\section{HYPOTHESIS TESTING AND INDEPENDENCY ANALYSIS}

Building regressions and scatterplots to measure the relationship between IPO and market performance is meaningless due to the non periodical aspect of issuance and to the pure correlation chance that we might have between IPO's size and market index returns or values. The purpose of this study is not to detect significant relationships or to produce equations to shape such correlation; rather it is to examine Dubai market's reaction to each IPO operation. Therefore, carrying out hypothesis testing is able to answer our inquiry for Dubai market. We assumed the following hypothesis:

Ho: There is no relationship or positive relationship between IPO's issuance ${ }^{9}$ and market return Ha: There is a negative relationship between IPO's and market return.

\footnotetext{
${ }^{9}$ As measured by their size.
} 
We are considering difference between average return when IPO is not issued and difference when IPO is issued. One tailed tes $\mathrm{t}^{10}$ is representative enough for Ha with a value greater than the null value of zero. Therefore we divided the sample into two categories:

1. Category (0) that represents returns when IPO is not issued.

2. Category (1) that represents market returns when IPO is issued.

Figure 4 illustrates the difference between these two categories.

Figure 4: Comparative Boxplots Between Category (0) And (1)

\section{Box Plot of Comparison of Returns / Data Set \#2}
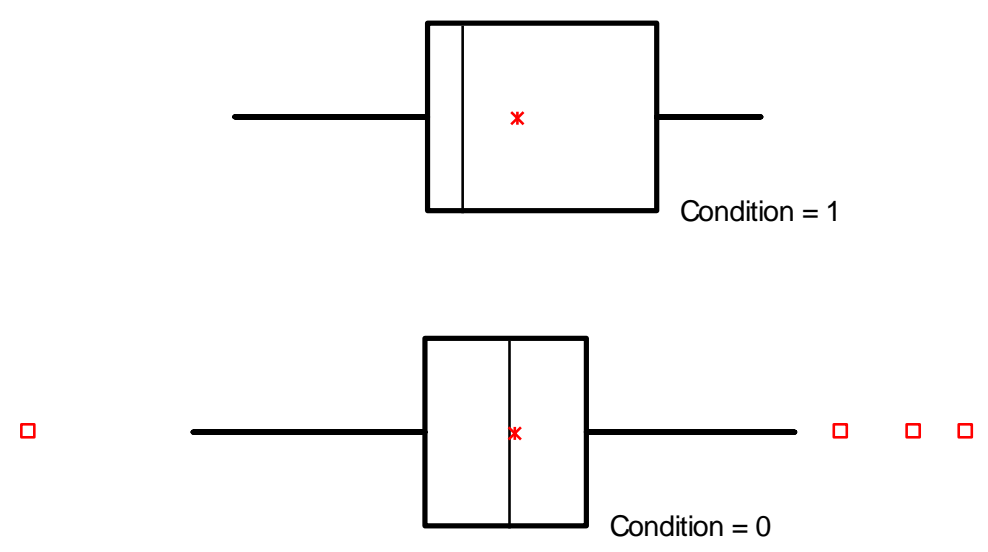

\begin{tabular}{lllllllll}
\hline-0.2 & -0.15 & -0.1 & -0.05 & 0 & 0.05 & 0.1 & 0.15 & 0.2
\end{tabular}

Even if the average return is almost the same in both cases, it could not be representative because of the heavy skewness of category ( 0 ), shown by important mild outliers mostly to the right and forcing the average return to be almost the same. On the other hand, we can notice the divergence between the two medians which reflect the real behavior of Dubai market. A closer analysis is illustrated in table 3 .

Important results are shown in table 3:

1. Highest returns were realized in category ( 0 ) before or well after IPO's issuance.

2. Heavy skewness and opposite skewness in both cases. Without IPO, returns distribution is skewed to the right which is obviously translated with the outliers. Unlike the negative skewness $(-5.4 \%)$ at issuance.

3. Only medians are to be considered for comparison purpose, therefore, we can conclude that IPO's issuance had a negative impact on the market performance $(-0.5 \%)$ when compared to an average positive return of $1.07 \%$ in normal periods.

4. More volatility during IPO's issuance despite the relatively limited operations during the period 2004-2006.

Table 3: One Variable(s) Summary

${ }^{10}$ Stacked option has been considered. 


\begin{tabular}{|c|c|c|}
\hline One Variable Summary & Returns (0) & Returns (1) \\
\hline Mean & $1.26 \%$ & $0.28 \%$ \\
\hline Variance & $0.28 \%$ & $5.28 \%$ \\
\hline Std. Dev. & $5.32 \%$ & $-5.47 \%$ \\
\hline Skewness & $7.07 \%$ & $248.90 \%$ \\
\hline Kurtosis & $410.50 \%$ & $-0.50 \%$ \\
\hline Median & $1.07 \%$ & $4.16 \%$ \\
\hline Mean Abs. Dev. & $3.91 \%$ & $-8.27 \%$ \\
\hline Minimum & $-15.32 \%$ & $9.69 \%$ \\
\hline Maximum & $16.67 \%$ & $-1.67 \%$ \\
\hline 1st Quartile & $-1.75 \%$ & $6.15 \%$ \\
\hline 3rd Quartile & $3.72 \%$ & $7.82 \%$ \\
\hline Interquartile Range & $5.48 \%$ & \\
\hline
\end{tabular}

Table 4 provides the details of the market hypothesis testing using equal and unequal variances tests.

Table 4: Hypothesis Testing Output

\begin{tabular}{|c|c|c|}
\hline Sample Summaries & Returns (0) & Returns (1) \\
\hline Sample Size & 92 & 0.01292 \\
\hline Sample Mean & 0.01262 & 0.05276 \\
\hline Sample Std Dev & 0.05315 & Unequal \\
\hline & & Variances \\
\hline Hypothesis Test (Difference of Means) & Variances & $>0$ \\
\hline Hypothesized Mean Difference & 0 & -0.00031 \\
\hline Alternative Hypothesis & $>0$ & 0.016208157 \\
\hline Sample Mean Difference & -0.00031 & 14 \\
\hline Standard Error of Difference & 0.016300442 & -0.0189 \\
\hline Degrees of Freedom & 102 & 0.5074 \\
\hline t-Test Statistic & -0.0188 & Don't Reject \\
\hline p-Value & 0.5075 & Don't Reject \\
\hline Null Hypoth. at 10\% Significance & Don't Reject & Don't Reject \\
\hline Null Hypoth. at 5\% Significance & Don't Reject & \\
\hline Null Hypoth. at 1\% Significance & Don't Reject & \\
\hline Equality of Variances Test & & \\
\hline Ratio of Sample Variances & & \\
\hline p-Value & 1.0147 & \\
\hline
\end{tabular}

With a high p-value for the equality of variances test (.93), we can't reject the equal variance ${ }^{11}$ assumption that gives enough evidence to make it impossible to reject the null hypothesis defined above. Therefore, there is no relationship (or positive relationship) between IPO issuance and market return.

\section{CONCLUSION}

\footnotetext{
${ }^{11}$ That shows a p-value of 50.75
} 
We were able throughout this paper to solve the myth of IPO's impact on Dubai Stock Market. Doubts about the market's reaction to IPO operations were clarified through detailed distribution analysis and hypothesis testing. Confusion between an expected increase of IPO's prices and market increase has been removed. It was shown that IPO had downbeat impact on Dubai market performance in terms of return as revealed by the rejection of the alternative hypothesis. This analysis does not suggest that every IPO that had an important initial return experienced poor medium-term performance. The independency showed in the above test may be partially attributed to irrational valuations at the time of IPO, which are or would be corrected over time. IPO operations were not behind what few analysts named it "markets crash". Other factors, not considered in this paper, might have been behind the market fluctuations. In addition, IPO's operations constitute a new event to this market and might, consequently, generate uncertainty in the global market behavior especially that the majority of investors are still following their sentiment rather than fundamentals ${ }^{12}$. The general weak performance of the market may be also partially attributed to the firm's managers, who may spend excessively and be less efficient with the firm's funds than they were before the IPO. A curious question is now to be examined, how and when Dubai stock market would better shape the timing, the pricing, and the long term impact of IPO on the financial market as a whole?

\section{REFERENCES}

1. Dickey, D. A. and Fuller, W. A. (1979), Distributions of the Estimators for Autoregressive Time Series With a Unit Root, Journal of the American Statistical Association, 74, 427-31.

2. Jeff Madura, (2003), Financial Markets and Institutions, $6^{\text {th }}$ edition, Thomson-Southwestern.

3. Johansen, S. (1988), Statistical Analysis of Cointegrating Vectors, Journal of Economic Dynamics and Control, 12, 231-54.

4. Johansen, S. (1991), Estimation and Hypothesis Testing of Cointegration in Gaussian Vector Autoregressive Models, Econometrica, 59, 1551-80.

5. Levine, R. and Renelt, D. (1992), A sensitivity Analysis of Cross-country Growth Regressions, American Economic Review, 82, 942-64.

6. Naïmy V. (2003), Marchés émergents, financement des PME et croissance économique: étude du cas libanais NDU Press.

7. Naimy V. (2005), Measuring the Effect of Financial Liberalization On The Supply Of Credit To The Private Sector: The Case Of Lebanon. The International Business And Economics Research Journal, ISSN 15350754, Volume 4, Number 5, May 2005, p. 17-30.

8. Naimy V. (2006), The Black-Scholes Model Guideline for Options Course as Taught at Notre Dame University- Lebanon, The Journal of Business \& Economics Research, Volume 4, Number 1, January 2006, p. 59-64.

9. Naimy V. (2006), Measuring, Adjusting, and Forecasting Beta: The Case of All the Lebanese Listed Firms, The Journal of Business \& Economics Research, Volume 4, Number 4, April 2006 p. 53-63.

10. Naimy V., Independency or Correlation? The GCC Stock Markets, Interest Rates, and Oil Prices: Against All Financial Rules, Journal of Business and Economics Research, to appear in February 2007.

11. Palisade StatTools 1.1, advanced statistical analysis for spreadsheets.

12. Sala-i-Martin, X. (1997), I just run two million regressions, AEA Papers and Proceedings, 87, 178-83.

13. $\quad$ http://portal.adsm.ae

14. http://www.tadawul.com.sa/

15. http://www.msm.gov.om/

16. www.finance.gov.lb

17. www.Mideastweb.com

\footnotetext{
${ }^{12}$ Naimy V., "Financial Ratios and Stock Prices: Consistency or Discrepancy? Longitudinal Comparison between UAE and USA", Working paper to be submitted to the 2006 International Business and Economics Research Conference, Nevada - USA.
} 